\title{
STRUKTUR KEPEMILIKAN DAN KONSERVATISME AKUNTANSI
}

\author{
Krismiaji \\ Akademi Akuntansi YKPN, Yogyakarta, Indonesia \\ Email:xmiaji@gmail.com
}

\begin{abstract}
This research investigates the effect of ownership structure on accounting conservatism in companies listed on the Indonesia Stock Exchange from 2016 to 2018. The sampling was carried out using a purposive method and produced a sample of 149 companies with a total of 447 company-year observations. Conservatism is measured using the accrual method while ownership structure is calculated using the Herfindahl index. This study obtained evidence that concentrated ownership structure positively affects accounting conservatism. This research contributes to the literature by introducing a hybrid approach in the form of the Herfindahl index in measuring the density or density of share ownership.
\end{abstract}

\section{Keywords: conservatism, Herfindahl index, ownership structure}

\begin{abstract}
ABSTRAK
Riset ini menginvestigasi efek konsentrasi kepemilikan pada konservatisme akuntansi yang diterapkan oleh perusahaan publik Indonesia dengan tahun pengamatan 2016 sampai 2018. Penentuan data sampel dilakukan dengan mengadopsi purposive sampling dan menghasilkan sampel sejumlah 149 perusahaan dengan total observasi sebanyak 447 tahun-perusahaan. Konservatisme diukur menggunakan metode akrual sedangkan struktur kepemilikan diukur menggunakan indeks Herfindahl. Penelitian ini memperoleh bukti bahwa struktur kepemilikan terkonsentrasi secara positif mempengaruhi konservatisme akuntansi. Penelitian ini memberikan kontribusi bagi literatur berupa pendekatan hybrid berupa indeks Herfindahl dalam mengukur densitas atau kepadatan kepemilikan saham.
\end{abstract}

Kata kunci: konservatisme, indeks Herfindahl, struktur kepemilikan

\section{KETERANGAN ARTIKEL}

Riwayat Artikel: diterima: 3 September 2020; direvisi: 26 November 2020; disetujui: 2 Desember 2020 Klasifikasi JEL: M41

Cara Mensitasi: Krismiaji. (2020). Struktur Kepemilikan dan Konservatisme Akuntansi. JIAFE (Jurnal IImiah Akuntansi Fakultas Ekonomi), 6(2), 149-160. https://doi.org/10.34204/jiafe.v6i2.2358

Copyright@2020. JIAFE (Jurnal Akuntansi Ilmiah Fakultas Ekonomi) Universitas Pakuan

\section{PENDAHULUAN}

Penelitian ini menginvestigasi efek struktur kepemilikan saham terhadap konservatisme akuntansi pada perusahaan publik dalam industri manufaktur dengan tahun pengamatan 2016-2018. Penelitian ini dimotivasi oleh hasil penelitian terdahulu yang menghasilkan temuan campuran, yaitu ada yang berefek positif, ada yang berefek negatif, dan ada yang tidak berpengaruh.

Transparansi dan ketepatwaktuan informasi akuntansi menjadi semakin penting dalam pelaporan keuangan karena meningkatnya globalisasi dan internasionalisasi di pasar modal. Salah satu konsep yang mempengaruhi transparansi dan ketepatwaktuan informasi ini adalah konservatisme (Ne dan Ma, 2015). Konservatisme atau prudence adalah proses penentuan nilai agar aset dan penghasilkan tidak dilaporkan terlalu tinggi dan liabilitas dan beban tidak dilaporkan terlalu rendah (International Accounting Standards Board/IASB, 2018). Konservatisme dalam 
Krismiaji: Struktur Kepemilikan dan ...

akuntansi sudah dikenal sejak lama, yaitu ketika Bliss (1924) mendefinisikan konservatisme sebagai antisipasi tidak ada laba namun mengantisipasi rugi. Menurut Financial Accounting Standard Board/FASB (1980) konservatisme adalah kehati-hatian dalam bersikap untuk memastikan telah diperhitungkannya ketidakpastian peristiwa yang akan datang dan risiko bawannya secara memadai. Selanjutnya Watts dan Zimmerman (1986) menyatakan bahwa konservatisme adalah aturan yang harus digunakan untuk melaporkan nilai lebih rendah diantara alternatif nilai aset dan melaporkan nilai tertinggi untuk liabilitas, dan (Basu, 1997) yang menginterpretasikan konservatisme untuk menggambarkan kecenderungan akuntan yang mensyaratkan verifikasi tingkat tinggi bagi pengakuan berita baik dibanding berita buruk. Hal ini perlu dilakukan karena dampaknya berita buruk bagi laba yang dilaporkan lebih cepat dibanding dampak berita baik. Konservatisme akuntansi merupakan metode yang digunakan oleh perusahaan dalam mengurangi risiko dalam pelaporan akuntansi yang muncul dari peristiwa yang belum pasti dampaknya terhadap laba (Kwon, 2005).

Peningkatan profitabilitas investasi bisnis merupakan motivasi utama diterapkannya konservatisme akuntansi. (Lalbar, dkk., 2012). Hal ini dikonfirmasi oleh Aminu dan Hassan (2017) yang menyatakan bahwa konservatisme akuntansi secara positif berpengaruh terhadap keputusan yang dibuat. Dengan demikian, konservatisme akuntansi merupakan fitur penting dan proksi kualitas informasi akuntansi (An, 2015), sehingga konservatisme akuntansi juga cenderung dipengaruhi oleh faktor-faktor governance (Song, 2015). Struktur kepemilikan, yang menggambarkan pengaturan kepemilikan dan menentukan kendali sebuah perusahaan merupakan hal yang fundamental dalam tata kelola perusahaan. Proporsi kepemilikan saham pada perusahaan publik biasanya memiliki pengaruh terhadap pelaporan keuangan sehingga juga berpengaruh terhadap konservatisme akuntansi.

Sejak model empiris yang disebut dengan inverse regression method dikenalkan oleh Basu (1997), riset yang menginvestigasi konservatisme telah banyak dilakukan, terutama yang berhubungan dengan struktur kepemilikan. Meskipun demikian, hasil penelitian tersebut tidak konsisten. Riset tentang efek kepemilikan institusi terhadap konservatisme akuntansi yang dilakukan oleh El-haq (2019); Putra, Sari, dan Larasdiputra (2019) dan Ramalingegowda dan Yu (2012) menghasilkan temuan positif, sedangkan penelitian oleh Risdiyani dan Kusmurianto (2015) menghasilkan temuan negatif, dan penelitian oleh Savitri (2018) melaporkan tidak ada pengaruh.

Hasil penelitian terkini tentang pengaruh kepemilikan saham terhadap konservatisme akuntansi yang dilaksanakan oleh Dewi dan Suryanawa (2014); Pambudi (2017); dan Putra et al. (2019) menghasilkan temuan positif, sedangkan penelitian oleh Ayuningsih, dkk (2016); Eersteling (2017); Fatmariani (2013); Lafond dan Roychowdhury (2008); dan Wardhani (2007) menghasilkan temuan negatif, dan penelitian oleh El-haq (2019); Petra (2018); Risdiyani, dkk (2015); Viola, dkk (2016); dan Wulandari, dkk (2014) melaporkan tidak ada pengaruh.

Hasil riset di atas memberikan peluang untuk melakukan riset lanjutan dengan memperbarui pengukuran variabel kepemilikan, yaitu menggunakan pendekatan hybrid atau gabungan yang disebut dengan indeks herfindahl. Riset ini bertujuan untuk membuktikan bagaimana dampak kepemilikan saham terkonsentrasi, yang diukur dengan pendekatan hybrid, terhadap konservatisme akuntansi pada perusahaan publik dalam industri manufaktur dengan tahun pengamatan 2016 - 2018.

Riset ini memberikan dua kontribusi. Pertama dengan pendekatan ini maka celah metodologi dapat terisi. Kedua, hasil penelitian juga dapat memperkaya literatur 
sejenis dengan menggunakan data terkini yang berasal dari pasar modal yang sedang berkembang BEI. Sebagai tambahan, riset ini juga penting dilakukan karena, (1) meskipun telah banyak penelitian sejenis, namun ada ketidak konsistenan hasil dan (2) penggunaan rerangka konseptual pelaporan keuangan baru yang tidak memasukkan konservatisme atau prudence sebagai salah satu unsur kualitas, padahal bukti empiris yang dikemukakan di atas menunjukkan bahwa konservatisme merupakan salah satu unsur dan proksi kualitas informasi.

Artikel ini diorganisasi sebagai berikut. Setelah memaparkan latar belakang yang yang berisi practical gap, hasil riset terdahulu, gap metodologi, tujuan riset dan kontribusi riset, sesi 2 membahas kajian literatur dan pengembangan hipotesis. Bagian 3 menguraikan detail dari metode penelitian diadopsi. Setelah memaparkan hasil pengolahan dana dan pembahasan di bagian 4, naskah ini diakhiri dengan kesimpulan di sesi 5 .

\section{KAJIAN LITERATUR DAN PENGEMBANGAN HIPOTESIS}

Riset ini mendasarkan pada teori agensi karena alasan berikut. Konflik keagenan antara prinsipal atau pemilik dan agen atau manajer telah menjadi fokus dalam literatur corporate governance. Konsentrasi kepemilikan berpotensi membatasi masalah keagenan dan pada gilirannya meingkatkan kinerja korporasi (Hu dan Izumida, 2009). Efficient monitoring hypothesis menyatakan bahwa tingginya konsentrasi kepemilikan meningkatkan kemampuan pemegang saham untuk memonitor manajemen dengan biaya yang rendah. Selain itu pemegang saham dengan kepemilikan dominan dalam sebuah perusahaan menunjukkan keinginan kuat untuk memainkan peran secara aktif dalam berbagai keputusan korporasi (Grossman dan Hart, 1986). Dengan demikian, keberadaan pemegang saham mayoritas akan menurunkan masalah agensi dan pada gilirannya agen (manajemen) akan mengurangi tindakan yang menguntungkan diri sendiri dan lebih fokus pada tindakan yang menguntungkan prinsipal.

Berdasarkan logika teoretis tersebut, seharusnya kepemilikan saham mayoritas, baik kepemilikan institusi, kepemilikan manajerial, dan lain-lain berdampak positif terhadap konservatisme akuntansi, karena konservatisme pada dasarnya merupakan salah satu fitur dan proksi kualitas informasi (An, 2015). Hal ini juga ditegaskan oleh IASB (2018) yang menyatakan bahwa netralitas, yang merupakan salah satu dari tiga karakteristik faithful representation, didukung oleh penerapan prudence atau konservatisme. Penerapan prudence akan mengurangi perilaku oportunistik karena adanya verifikasi yang lebih ketat terhadap laba dibanding rugi (Watts, 2003), dan menurunkan asimetri informasi (Lafond dan Watts, 2008). Penerapan prudence tidak menyiratkan kebutuhan asimetri, yaitu kebutuhan adanya bukti yang meyakinkan untuk mendukung pengakuan aset atau pendapatan dibanding pengakuan kewajiban atau beban (International Accounting Standards Board/IASB, 2018). Konservatisme akuntansi bemakna pemilihan diantara praktik akuntansi yang berakibat pada estimasi lebih rendah nilai aset atau estimasi lebih tinggi nilai utang (Wolk, dkk., 2017)

Penelitian terdahulu tentang dampak kepemilihan saham mayoritas cenderung tidak konklusif atau tidak konsisten. Hasil penelitian yang melaporkan efek kepemilikan manajerial terhadap konservatisme akuntansi tidak dapat disimpulkan secara mudah. Persoalan utamanya adalah fakta bahwa manajer dapat membuat keputusan yang menguntungkan mereka dengan menyembunyikan kinerja ekonomi perusahaan sesungguhnya (Lara, dkk., 2020; Uwuigbe, dkk., 2018). Selain itu, praktik manajemen laba juga menyembunyikan pola pendapatan dan pertumbuhan laba, sehingga menimbulkan 
Krismiaji: Struktur Kepemilikan dan ...

kesan bahwa pemegang saham dan pihak berkepentingan lainnya dapat mengantisipasi peningkatan pertumbuhan perusahaan. Namun, menurut Lara, dkk., (2018), literatur terbaru menyajikan bukti bahwa konservatisme dapat berfungsi sebagai tindakan pencegahan atas kerugian yang disebabkan oleh praktik manajemen laba. Riset terdahulu yang meginvestigasi asosiasi antara kepemilikan manajemen dan konservatisme melaporkan bahwa kepemilikan manajerial dan konservatisme akuntansi berhubungan secara positif (Alkurdi, dkk., 2017; Dewi dkk., 2014; Pambudi, 2017; Putra dkk., 2019; Shuto, dkk., 2010; Utomo, dkk., 2018).

Investor asing cenderung tertarik pada perusahaan dengan investasi tinggi dan informasi berlimpah karena mereka meyakini informasi tersebut memiliki tingkat asimetri yang rendah (Lafond, dkk., 2008). Selain itu, mereka memiliki motif, pengalaman, dan keahlian yang lebih kuat untuk menganalisis perusahaan secara independen, dan hal ini pada gilirannya akan memengaruhi kebutuhan akan informasi yang akurat, sehingga mereka cenderung untuk menerapkan lebih banyak konservatisme. An (2015) menyatakan bahwa kepemilikan asing dapat meningkatkan kualitas pelaporan keuangan. Hasil riset membuktikan bahwa kepemilikan asing secara positif mempengaruhi konservatisme informasi keuangan. Studi yang dilakukan oleh Alkurdi dkk. (2017); Amos, dkk. (2016); dan An (2015) mengungkapkan hubungan positif antara kepemilikan asing dan konservatisme akuntansi.

Pemegang saham institusional adalah pemegang saham profesional utama, lebih independen dan lebih mampu mengakses informasi penting tentang prospek masa depan perusahaan dan strategi bisnis melalui hubungan langsung dengan manajer (Asiriuwa, dkk., 2019). Penggunaan kemampuan investor institusi untuk memantau manajemen dan kinerja perusahaan mengikuti jumlah investasi mereka. Semakin tinggi tingkat kepemilikan institusional, semakin baik manajemen. Dengan demikian, pemegang saham institusional memiliki power untuk mengontrol perilaku manajemen dan mencegah para investor dari berbagai kerugian akibat konflik keagenan (Yu, 2013).

Investor institusi mungkin memiliki insentif untuk memantau pelaporan keuangan. Bukti empiris menunjukkan bahwa keberadaan investor institusi memiliki hubungan positif dengan konservatisme akuntansi (Alkurdi, dkk., 2017; Amos dkk., 2016; El-haq, 2019; Putr, dkk., 2019; Ramalingegowda dan Yu, 2012). Sebagai tambahan, Yu (2013) melaporkan pengaruh positif kepemilikan blok terhadap konservatisme akuntansi, dan Li, dkk. (2017) melaporkan pengaruh positif kepemilikan pemerintah terhadap konservatisme akuntansi.

Meskipun hasil penelitian terdahulu tentang pengaruh keberadaan empat kelompok kepemilikan mayoritas yaitu kepemilikan institusi, manajerial, dan asing juga melaporkan pengaruh negatif dan tidak berpengaruh, namun riset ini mengambil posisi sesuai dengan teori bahwa keberadaan pemegang saham mayoritas mampu mempengaruhi manajemen untuk bertindak bagi kepentingan perusahaan dan pemegang saham. Berdasarkan kajian di atas, maka hipotesis riset dirumuskan sebagai berikut:

H1: Kepemilikan terkonsentrasi berpengaruh positif terhadap konservatisme akuntansi.

\section{METODE PENELITIAN}

Populasi yang digunakan dalam riset ini adalah seluruh perusahaan yang terdaftar BEI mulai tahun 2016 sampai 2018. Penentuan sampel dilakukan dengan mengadopsi metoda purposive dengan persyaratan: (1) perusahaan merupakan perusahaan publik yang listed bursa efek Indonesia pada tahun 2016 sampai 2018; (2) memiliki data lengkap, dan (3) bukan merupakan perusahaan keuangan. Sumber data meliputi laporan tahunan (annual report), 
database $\mathrm{BEI}$, dan website perusahaan. Hipotesis penelitian diuji dengan menggunakan model penelitian (1) berikut.

$$
\begin{aligned}
& K A K_{i t}=\alpha_{i t}+\beta_{1} K_{O N N_{i t}}+\beta_{2} S I Z E+ \\
& \beta_{3} P R O F_{i t}+\varepsilon_{i t}
\end{aligned}
$$

KAK adalah konservatisme akuntansi. Mengikuti Ahmed, dkk (2013), variabel ini diukur menggunakan metoda akrual dengan rumus (2), berikut.

$$
\mathrm{KAK}=\frac{\mathrm{LB}-\mathrm{AKO}+\mathrm{Dep}}{R A S_{t}}
$$

LB adalah laba bersih, AKO adalah arus kas bersih dari operasi, Dep adalah beban depresiasi, dan RAS adalah rerata aset. KAK dihitung rerata untuk 3 tahun yaitu $\mathrm{t}-1, \mathrm{t} 1$, dan $t+1$, kemudian dikalikan dengan negatif 1 . Perhitungan rerata waktu tiga tahun dimaksudkan untuk mengurangi efek akrual yang besar dan temporer. Jika KAK bernilai positif, berarti semakin konservatif. Konsep yang melandasai pengukuran ini adalah bahwa akuntansi konservatisme mengakibatkan akrual negatif persisten (Givoly, dkk., 2000).

Perhitungan rerata tiga tahun tersebut juga menjamin dimitigasinya akrual temporer yang besar, karena akrual cenderung berkebalikan dalam satu atau dua periode (Richardson, dkk., 2005). KON adalah konsentrasi kepemilikan dan menjadi variabel independen. KON diukur atau dihitung dengan indeks herfindahl. Indeks ini merupakan jumlah kuadrat kepemilikan saham untuk setiap kelompok pemegang saham dan memiliki nilai antara 0 dan 1 . Rumus perhitungan indeks adalah sebagai berikut.
$\mathrm{H}=\sum_{i=1}^{n}(\text { porsi kepemilikan saham })^{2}$

Semakin tinggi angka indeks, semakin tinggi derajat konsentrasi kepemilikan. Dalam riset ini digunakan dua variabel kontrol yang terdiri atas ukuran perusahaan (Size) dan kemampulabaan (PROF). Size dihitung dengan log total aset, sedangkan kemampulabaan diproksi dengan tingkat kembalian aset (return on assets) atau ROA yaitu laba bersih dibagi total aset.

\section{HASIL DAN PEMBAHASAN}

Berdasarkan proses penentuan sampel di atas, diperoleh data sampel sejumlah 149 perusahaan publik yang listed di BEI untuk periode tiga tahun dari 2016-2018, sehingga total observasi berjumlah 447 tahunperusahaan (firm-years).

\section{Analisis Univariat}

Data statistik deskriptif untuk seluruh variabel yang diteliti disajikan pada Tabel 1 . Hasilnya mengindikasikan bahwa seluruh variabel memiliki tingkat variasi yang rasional. Konservatisme akuntansi sebagai variabel dependen memiliki mean sebesar -15,298 dengan standar deviasi sebesar 49,630. Dengan angka minimal sebesar $-469,212$ dan angka maksimal sebesar 156,556 maka range data KAK tidak terlalu menyebar sehingga kemungkinan memiliki outlier sangat kecil. Konsentrasi kepemilikan (KON) yang merupakan variabel independen memiliki nilai mean 0,948 dengan nilai maksimal sebesar 0,995 dan nilai minimal sebesar 0,251. 
Krismiaji: Struktur Kepemilikan dan ...

Tabel 1. Statistik Deskriptif

\begin{tabular}{l|r|r|r|r|r}
\hline & \multicolumn{1}{|c|}{ Mean } & \multicolumn{1}{c|}{ Median } & \multicolumn{1}{l|}{ Maximum } & \multicolumn{1}{c|}{ Minimum } & \multicolumn{1}{c}{ Std. Dev. } \\
\hline KAK & $-15,298$ & $-2,913$ & 156,556 & $-469,212$ & 49,630 \\
\hline KON & 0,948 & 0,618 & 0,995 & 0,251 & 0,161 \\
\hline SIZE & 6,364 & 6,280 & 8,523 & 4,604 & 0,677 \\
\hline PROF & 0,061 & 0,043 & 0,921 & $-0,550$ & 0,108 \\
\hline
\end{tabular}

Konsentrasi kepemilikan (KON) yang merupakan variabel independen memiliki nilai mean 0,948 dengan nilai maksimal sebesar 0,995 dan nilai minimal sebesar 0,251 . Dengan nilai median sebesar 0,618, maka data ini menyiratkan bahwa konsentrasi kepemilikan sangat padat dan mendekati angka maksimum.

\section{Analisis Bivariat}

Analisis bivariate yang disajikan pada Tabel 2 memiliki dua tujuan. Pertama, analisis ini digunakan untuk melihat korelasi antar dua variabel yang diteliti, untuk mengetahui ada tidaknya multikolinieritas.

Tabel 2. Korelasi Pearson

\begin{tabular}{l|l|l|l}
\hline & KAK & KON & SIZE \\
\hline KON & $0,154^{* *}$ & & \\
\hline SIZE & $-0,034$ & $-0,004$ & \\
\hline PROF & $0-, 390^{* *}$ & 0,065 & $0,100^{*}$ \\
\hline$* * *$ signifikan pada level $1 \%$ dan $5 \%$
\end{tabular}

Hasil analisis mengindikasikan kewajaran koefisien korelasi antar variabel dan tidak ada angka yang melebihi batas toleransi. Kedua, analisis ini bertujuan untuk melakukan penilaian awal pengaruh variabel independen, dalam hal ini adalah KON, terhadap variabel dependen, yaitu KAK, dengan koefisien korelasi sebesar 0,154 dan signifikan pada level $1 \%$. Hal ini merupakan indikasi awal bahwa konsentrasi kepemilikan berpengaruh positif terhadap konservatisme akuntansi. Meskipun demikian, investigasi lebih mendalam untuk memastikan adanya efek konsentrasi kepemilikan (KON) terhadap konservatisme akuntansi (KAK) sekaligus untuk menguji hipotesis, akan dilakukan pada bagian berikutnya menggunakan analisis regresi.

\section{Analisis Multivariat}

Uji hipotesis dilakukan dengan mengadopsi ordinary least square (OLS). Pertama peneliti melakukan pengujian terhadap asumsi klasik. Dari hasil uji tersebut terbukti bahwa tidak ada pelanggaran normalitas data dan tidak ada multikolinieritas, heteroskedastisitas, dan otokorelasi serta tidak ada outlier. Hasil analisis regresi disajikan pada Tabel 3.

Variabel utama yang menjadi perhatian dalam riset ini adalah KON. Hasil analisis regresi yang disajikan di Tabel 3, menunjukkan bahwa koefisien regresi untuk variabel KON bernilai 0,228 dan signifikan pada level $1 \%$ ( $p$ $<0.001$ ). Hasil ini bermakna bahwa semakin terkonsentrasi kepemilikan saham perusahaan, semakin konservatif informasi akuntansi yang dilaporkan. Oleh karena itu, hipotesis 1 yang menetapkan efek positif kepemilikan terkonsentrasi terhadap konservatisme akuntansi terbukti dan dikonfirmasi oleh data empiris. Hasil ini inline dengan hasil riset terdahulu yang dilaporkan oleh Alkurdi, dkk. (2017; Amos, dkk. (2016); El-haq (2019); Putra, dkk. (2019); dan Ramalingegowda, dkk. (2012) yang melaporkan bahwa kepemilikan institusi berhubungan secara positif dengan konservatisme akuntansi. Hasil di atas juga sesuai dengan hasil riset yang dilaporkan oleh Alkurdi dkk. (2017); Amos, dkk. (2016); dan An (2015) yang membuktikan adanya hubungan positif antara kepemilikan asing dan konservatisme akuntansi, serta hasil riset yang dilaporkan oleh Alkurdi, dkk. (2017); Dewi, dkk. (2014); Pambudi (2017); Putra, dkk. (2019); Shuto, dkk. (2010); dan Utomo, dkk. 
(2018) yang membuktikan adanya hubungan positif antara kepemilikan manajerial dan konservatisme akuntansi.

Hasil penelitian ini juga mengkonfirmasi teori agensi yang menjelaskan dan memprediksi bahwa kepemilikan mayoritas memiliki insentif untuk melakukan monitoring yang lebih baik. Selain itu pemegang saham cenderung memainkan peran lebih aktif dalam berbagai keputusan korporasi.

Tabel 3. Analisis Regresi

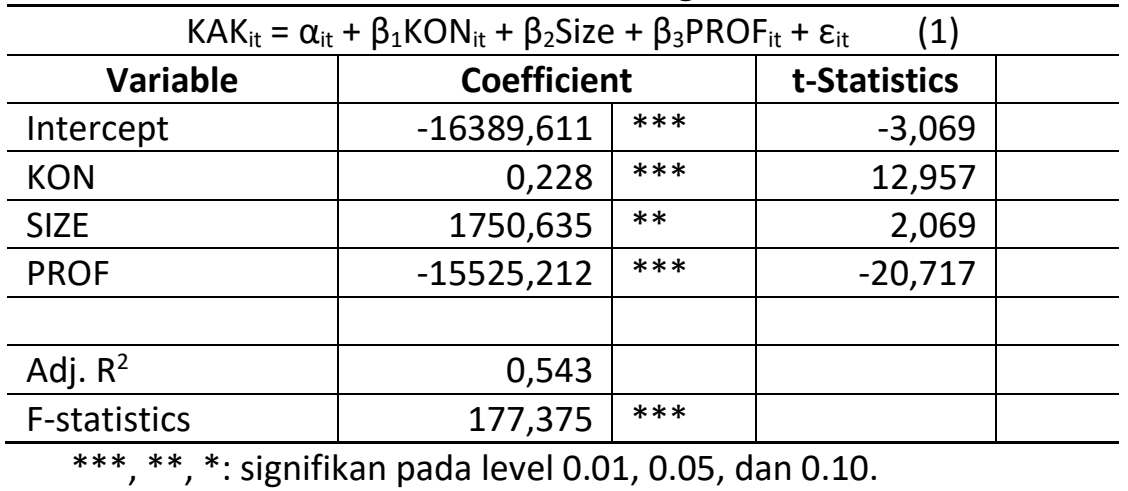

Dengan demikian, keberadaan pemegang saham mayoritas akan menurunkan masalah agensi dan pada gilirannya agen (manajemen) akan mengurangi tindakan yang menguntungkan diri sendiri dan lebih fokus pada tindakan yang menguntungkan prinsipal.

Rerangka konseptual akuntansi keuangan memang tidak memuat konservatisme sebagai karakteristik kualitatif informasi keuangan, karena konservatisme dianggap bertentangan dengan sifat netral yang merupakan komponen pendukung faithful representation. Meskipun demikian, konservatisme tetap menjadi bagian penting dari kualitas informasi akuntansi, sehingga tetap dicantumkan dalam rerangka konseptual dengan istilah baru yaitu prudence, di luar karakteristik kualitatif. Oleh karena itu, dalam standar akuntansi ada ketentuan tentang uji impairment untuk aset yang dilaporkan dengan basis nilai wajar.

Monitoring merupakan aktivitas kunci yang memberikan jaminan bahwa tindakan manajemen diarahkan untuk kepentingan dan keuntungan pemegang saham, khususnya dalam penyajian informasi yang berkualitas, adalah monitoring. Dengan semakin besar porsi kepemilikan, maka kekuatan monitoring yang dimiliki oleh pemegang saham juga semakin besar. Oleh karena itu, jika hasil penelitian tentang pengaruh setiap kelompok kepemilikan, misalnya manajerial, institusional, asing, keluarga, dan sebagainya, terhadap konservatisme ada yang negatif atau bahkan tidak berpengaruh, kemungkinan besar para pemegang saham tidak mampu memanfaatkan insentif dan power monitoringnya secara optimal.

Jika dihubungkan dengan teori, hasil penelitian terdahulu yang menyatakan bahwa kepemilikan mayoritas (manajerial, institusional, dan sebagainya) berhubungan secara negatif atau tidak berhubungan dengan konservatisme memang tidak sesuai. Tidak ada yang salah dengan temuan tersebut demikian pula dengan teorinya. Hasil penelitian empiris seharusnya justru dapat digunakan untuk menguji teori, karena teori bukan hukum yang selalu benar dalam semua kondisi dan waktu, sedangkan teori tidak selalu benar meskipun biasanya benar.

\section{PENUTUP}

Penelitian ini menguji efek konsentrasi kepemilikan saham terhadap konservatisme akuntansi yang diterapkan oleh perusahaan 
publik dalam industri manufaktur dalam rentang tahun 2016-2018. Dengan menggunakan pendekatan hybrid untuk mengukur struktur kepemilikan, penelitian ini memperoleh bukti empiris bahwa struktur kepemilikan yang terkonsentrasi secara positif mempengaruhi konservatisme akuntansi.

Hasil ini tidak hanya mengkonfirmasi sebagian penelitian terdahulu yang mengukur struktur kepemilikan secara parsial, yaitu kepemilikan manajerial, kepemilikan institusi, dan sebagainya, namun hasil penelitin juga mengkonfirmasi teori agensi yang memprediksi bahwa semakin tinggi persentase kepemilikan saham, maka semakin tinggi insentif dan power untuk melakukan monitoring. Teori agensi juga menjelaskan bahwa keberadaan pemegang saham mayoritas akan menurunkan masalah agensi, sehingga agen (manajemen) akan lebih fokus pada tindakan yang menguntungkan prinsipal.

Penelitian ini paling tidak memiliki satu implikasi yaitu implikasi metodologis dan teoritis. Penggunaan indeks herfindahl dalam riset konservatism selain memperkaya literatur sejenis, juga dapat digunakan untuk mengkonfirmasi hasil penelitian yang tidak konsisten dan juga untuk melakukan uji robustness, atau sebaliknya. Penggunan indeks dapat mengukur secara lebih komprehensif dibandingkan pendekatan pengukuran parsial.

Riset ini memiliki limitasi, yaitu hanya menggunakan data perusahaan yang terdaftar di BEI. Oleh karena itu, generalisasi hasil mungkin terbatas untuk wilayah yurisdiksi Indonesia saja atau mungkin ditambah dengan negara lain yang memiliki kondisi mirip dengan Indonesia. Keterbatasan ini membuka peluang penelitian lanjutan dengan memperluas data dengan memasukkan data perusahaan yang terdaftar bursa efek negara lain, khususnya negara maju yang memiliki kultur yang berbeda. Dengan kultur yang berbeda, pola monitoring yang dilakukan oleh pemegang saham mayoritas juga berbeda, sehingga hasilnya diharapkan lebih konsisten dan sesuai dengan teori. Peluang penelitian lanjutan dapat pula dilakukan dengan memperluas jenis konservatisme menjadi konservatisme kondisional dan konservatisme nonkondisional. Peluang penelitian lanjutan ketiga adalah dengan melibatkan mekanisme intern untuk memastikan manajemen bertindak untuk kepentingan pemegang saham, misalnya melibatkan karakteristik komite audit yang dimiliki oleh perusahaan.

\section{REFERENSI}

Ahmed, A. S. dan Duellman, S. (2013). Managerial Overconfidence and Accounting Conservatism. Journal of Accounting Research, 51(1), 1-30. https://doi.org/10.1111/j.1475679X.2012.00467.x

Alkurdi, A., dkk. (2017). Accounting Conservatism and Ownership Structure Effect: Evidence from Industrial and Financial Jordanian Listed Companies. International Journal of Economics and Financial Issues, 7(2), 608-619.

Aminu, L. dan Hassan, S. U. (2017). Accounting conservatism and financial performance of Nigerian Deposit Money Banks : An analysis of recent economic recession. Scholedge International Journal of Business Policy \& Governance, 4(12), 124-135.

https://doi.org/10.19085/journal.sijbpg 041201

Amos, B., dkk. (2016). The impact of institutional ownership structure on earnings quality of listed food/beverages and tobacco firms in Nigeria. Journal of Arts, Science \& Commerce, $\quad 7(1), \quad 20-30$. https://doi.org/10.18843/rwjasc/v7i1(1) /03

An, Y. (2015). Does foreign ownership increase financial reporting quality? Asian Academy of Management Journal, 20(2), 81-101.

Asiriuwa, O., dkk. (2019). Ownerships Structures and Accounting Conservatism 
among Nigeria Listed Firms. IOP Conference Series: Earth and Environmental Science, 331(1). https://doi.org/10.1088/17551315/331/1/012056

Ayuningsih, L. D., dkk. (2016). Pengaruh Debt Covenant, Kepemilikan Manajerial, dan Growth Opportunities terhadap Konservatisme Akuntansi. Kajian Akuntansi, 17(2), 19-30.

Basu, S. (1997). The conservatism principle and the asymmetric timeliness of earnings 1. Journal of Accounting and Economics, 24((1997)), 3-37.

Bliss, J. H. (1924). Management Through Accounts. New York: The Ronald Press Company.

Dewi, N. K. S. L. dan Suryanawa, I. K. (2014). Pengaruh Struktur Kepemilikan Manajerial, Leverage, Dan Financial Distress Terhadap Konservatisme Akuntansi. E-Jurnal Akuntansi, 7(1), 223-234.

Eersteling, G. (2017). The effect of managerial ownership on the demand for conservatism. In The effect of managerial ownership on the demand for conservatism.

El-haq, Z. N. S. (2019). Pengaruh Kepemilikan Manajerial, Kepemilikan Institusional, Growth Opportunities, Dan Profitabilitas Terhadap Konservatisme Akuntansi. Jurnal Aset (Akuntansi Riset), 11(2), 315-328.

https://doi.org/10.17509/jaset.v11i2.19 940

Fatmariani. (2013). Pengaruh struktur kepemilikan, debt covenant dan growth opportunities terhadap konservatisme akuntansi pada perusahaan manufaktur yang terdaftar di Bursa Efek Indonesia. Jurnal Akuntansi, 1(2), 1-20.

Financial Accounting Standard Board (FASB). (1980). Statement of Financial Accounting Concept No. 2., Qualitative Characteristics of Accounting
Information. Norwalk, Connecticut: Financial Accounting Standards Board.

Givoly, D. dan Hayn, C. (2000). The changing time-series properties of earnings, cash flows and accruals: Has financial reporting become more conservative? Journal of Accounting and Economics, 29(3), 287-320. https://doi.org/10.1016/S01654101(00)00024-0

Grossman, S. J. dan Hart, O. D. (1986). The costs and benefits of ownership: A theory of vertical and lateral integration. Journal of Political Economy, 94(4), 691-719. https://doi.org/10.1086/261404

Hu, Y. dan Izumida, S. (2009). The relationship between ownership and performance: A review of theory and evidence. International Business Research, 1(4), 72-81.

https://doi.org/10.5539/ibr.v1n4p72

International Accounting Standards Board (IASB). (2018). Conceptual framework for financial reporting. In Business Accounting.

https://doi.org/10.1007/978-1-13700662-2_5

Kwon, Y. K. (2005). Accounting conservatism and managerial incentives. Management Science, 51(11), 16261632. https://doi.org/10.1287/mnsc.1050.041 7

Lafond, R. dan Roychowdhury, S. (2008). Managerial ownership and accounting conservatism. Journal of Accounting Research, 46(1), 101-135. https://doi.org/10.1111/j.1475679X.2008.00268.x

Lafond, R. dan Watts, R. L. (2008). The information role of conservatism. The Accounting Review, 83(2), 447-478.

Lalbar, A., dkk. (2012). A study of the relationship between accounting conservatism and investment efficiency 
in Tehran Stock Exchange. Journal of Basic and Applied Scientific Research, 2(6), 5719-5725.

Lara, J. M. G., dkk. (2020). Conditional conservatism and the limits to earnings management. Journal of Accounting and Public Policy, 39(4), 1-55. https://doi.org/https://doi.org/10.1016 /j.jaccpubpol.2020.106738

Li, W. X. B., dkk. (2017). Revisiting conditional accounting conservatism in statecontrolled firms. Asian Review of Accounting, 25(4), 486-501.

$\mathrm{Ne}$, R., dan Ma, E. (2015). Identifying accounting conservatism - A literature review. Procedia Economics and Finance, 32(2015), 1114-1121. https://doi.org/10.1016/S22125671(15)01576-2

Pambudi, J. E. (2017). Pengaruh kepemilikan manajerial dan debt covenant terhadap konservatisme akuntansi. Competitive, 1(1), 88-110.

Petra, G. D. (2018). Pengaruh kepemilikan manajerial, proporsi komisaris independen, dan political cost terhadap konservatisme akuntansi. Universitas Islam Indonesia.

Putra, I. G. B. N. P., dkk. (2019). Pengaruh kepemilikan institusional dan kepemilikan manajerial pada konservatisme akuntansi. Wacana Ekonomi (Jurnal Ekonomi, Bisnis Dan Akuntansi), 18(1), 41-51.

Ramalingegowda, S. dan Yu, Y. (2012). Institutional ownership and conservatism. Journal of Accounting and Economics, 53(1-2), 98-114. https://doi.org/10.1016/j.jacceco.2011. 06.004

Richardson, S. A., dkk. (2005). Accrual reliability, earnings persistence and stock prices. Journal of Accounting and Economics, 39(3), 437-485. https://doi.org/10.1016/j.jacceco.2005. 04.005

Risdiyani, F. dan Kusmurianto. (2015). Analisis faktor-faktor yang mempengaruhi penerapan konservatisme akuntansi. Accounting Analysis Journal, 4(3), 1-10.

Savitri, E. (2018). Pengaruh struktur kepemilikan institusional, debt covenant dan growth opportunities terhadap konservatisme akuntansi. Jurnal Allqtishad, 12(1), 39. https://doi.org/10.24014/jiq.v12i1.4444

Shuto, A. dan Takada, T. (2010). Managerial ownership and accounting conservatism in Japan: A test of management entrenchment effect. Journal of Business Finance and Accounting, 37/78), $815-840$. https://doi.org/10.1111/j.14685957.2010.02196.x

Song, F. (2015). Ownership structure and accounting conservatism: A literature review. Modern Economy, 6(4), 478483.

Utomo, S. D., dkk. (2018). The moderating effects of managerial ownership on accounting conservatism. Academy of Accounting and Financial Studies Journal, 22(6), 1-11.

Uwuigbe, U., dkk. (2018). Corporate governance and quality of financial statements: a study of listed Nigerian banks. Banks and Bank Systems, 13(3), 12-23.

https://doi.org/10.21511/bbs.13(3).201 8.02

Viola dan Diana, P. (2016). Pengaruh kepemilikan managerial, leverage, financial distress dan kepemilikan publik terhadap konservatisme akuntansi (Studi pada Perusahaan Manufaktur yang Terdaftar di Bursa Efek Indonesia Periode 2012-2014). Ultima Accounting, $8(1), 22-36$.

Wardhani, R. (2007). Tingkat konservatisme akuntansi di indonesia dan hubungannya dengan karakteristik dewan sebagai salah satu mekanisme corporate governance.

Watts, R. L. (2003). Conservatism in 
JIAFE (Jurnal Ilmiah Akuntansi Fakultas Ekonomi)

https://journal.unpak.ac.id/index.php/jiafe

accounting part I: Explanations and implications. Accounting Horizons, 17(3), 207-221. https://doi.org/10.2308/acch.2003.17.3 .207

Watts, R. L. dan Zimmerman, J. L. (1986). Positive Accounting Theory. New Jersey: Prentice-Hall.

Wolk, H. I., dkk. (2017). Accounting Theory: Conceptual Issues in a Political and Economic Environment (Ninth Edit).
Vol. 6 No. 2, Des 2020, Hal. 149-160

P-ISSN: 2502-3020, E-ISSN: 2502-4159

https://doi.org/10.4135/978150630010 8

Wulandari, I., dkk. (2014). Pengaruh struktur kepemilikan manajerial, debt covenant dan growth opportunities terhadap konservatisme akuntansi. Jurnal Online Mahasiswa Fakultas Ekonomi Universitas Riau, 1(2), 1-15.

Yu, K. (2013). Block ownership and accounting conservatism. Corporate Ownership \& Control, 10(3), 272-293. 
